\title{
Profiles of teaching and learning moments in the history classroom
}

\author{
Mariana Lagarto* - University of Porto, Portugal
}

\begin{abstract}
This paper reports on the main results of research carried out in Portuguese history classrooms (Grades 7-9, age 12-14), with the aim of providing further understanding of how historical thinking is being developed and assessed by teachers. Although history education research in Portugal appears to have fostered some fruitful experiences in this area, this study is intended to identify practices of teaching and learning. This work also tries to highlight good practices with relevance to the development of historical thinking.

In the main study, data were collected through direct observation of classroom interaction (followed by interviews with teachers) and paper-andpencil tasks (performed by students) focusing on change in history learning and metacognition. Inductive analysis and triangulation of the data helped to understand possible relationships between questioning in the classroom and thinking in history, and to highlight some features of how students' historical thinking is being developed, namely what kind of temporal orientation they construct.

Teachers revealed different kinds of teaching practices during a lesson, producing different kinds of learning experiences: a model of the development of competencies in history emerged from the data, and also a set of profiles of teaching and learning moments. Although seven profiles emerged, this paper will focus on Profile 7, as it could be the most inspiring for history education.
\end{abstract}

Keywords: historical competencies; history teaching and learning; assessment in history; temporal orientation

\section{Introduction}

This article reports on the main results of a study that focused on how historical competencies were developed and assessed by teachers of Grade 7 to Grade 9 classes in Portugal. The study was intended to contribute to a diagnosis of how historical thinking has been developed and to highlight some good practices, namely those that could have been inspired by history education research in Portugal, which has gained considerable dissemination through continuous teacher education. The Historical Consciousness - Theories and Practices Projects coordinated by Isabel Barca (www.fct. pt/apoios/projectos/consulta/vglobal_projecto.phtml.en?idProjecto=72623\&idElemC oncurso=903) made relevant contributions to this specific aspect of teacher education through workshops, MA dissertations and PhD theses. Teacher education based on these projects helped teachers to rethink their practices in order to help students make sense of history through the development of second-order concepts such as significance, empathy, historical evidence and narrative, ideas discussed by Lee (2001, 2005), Ashby (2003) and Rüsen (2004), among others. According to this disciplinary 
approach, lessons should focus on students' learning, and for that a 'constructivist' approach is considered desirable, as suggested by Ashby et al. (2005), Barca (2004) and Cooper and Chapman (2009).

Assessment should also focus on how students learn, and several proposals for assessing students' historical thinking in a conceptual progression have been presented, based on the work of the authors referred to above. Specific continuous teacher training based on these aims has been very important, in order to provide guidance on how to achieve the goals of the Portuguese national curriculum, which since 2001, has centred on competencies in historical knowledge (Barca, 2011). Teacher training also reflects research findings on history education, through the History Learning Goals published by the Ministry of Education in 2010.

However, despite efforts to disseminate a set of proposals grounded in history education research, the use of these proposals by teachers was limited by the dominance in the classroom of the transmission paradigm and an approach to assessment that centred on students' recall and reproduction of content transmitted by teachers (Fernandes, 2011; Roldão, 2003). These models persist, even though new trends in research point out the possibility of improving students' performance through tasks centred on cognitive competencies that should be assessed through observation of students-in-action and analysis of their metacognition (Alves and Machado, 2011; Roldão, 2003).

Given this context, and to better understand the teaching, learning and assessment practices in history, the research questions focus on what educational influences teachers perceive when they plan their lessons, and on how teaching, learning and assessment practices are developing students' historical thinking.

The further aim of this research is to contribute to the improvement of teachers' practices, in order to foster students' historical thinking in ways that are consistent with their needs in temporal orientation, thus helping them to develop some sort of genuine historical consciousness that 'ties the past to the present in a manner that bestows on present actuality a future perspective' (Rüsen, 2004: 67).

\section{Methodology}

This study mainly used a qualitative approach, inspired by grounded theory (Corbin and Strauss, 2008). It was developed through three phases (exploratory, pilot and final) with 6 teachers and 174 students as participants ( 3 teachers and 72 students in the exploratory phase; 2 teachers and 50 students in the pilot phase; 2 teachers and 52 students in the final phase). It was a non-random sample mainly focused on Grade 7 to Grade 9 history teachers and their students in the classroom, defined by convenience criteria due to resource constraints (Patton, 1990), such as time available to do research and the relative proximity of the field study (in this case, the Greater Lisbon area where the researcher lives). Each participant was given a fictional name to preserve anonymity.

The research techniques used in the exploratory study were enquiry and direct observation of classes-in-action. The instruments of enquiry were a brief questionnaire (about teachers' professional data) and a semi-structured interview guide, designed to try to understand what influences teachers' ideas and practices, and what they think about their teaching and the learning process. The questionnaire was completed at the beginning of the interview, which was conducted before the classroom observation. Classroom observation was chosen as it is well-known that an environment such as this can be relevant for better understanding the teaching and learning process, despite the challenge posed by its complexity (Erickson, 1985). 
The results of the exploratory phase highlighted the need to refine methods of data collection, and the enquiry instruments. Interviews took place after each lesson observation and some readjustments were made to the interview guide, in order to encourage a reflective dialogue and so gain a better understanding of teachers' perceptions of their teaching and assessment practices, and of student performance. In addition, written tasks suggested by the researcher were introduced. These focused on students' metacognition, their understanding of evidence, and of change in history, in order to have a better understanding of their historical thinking, because several students did not participate in oral interaction in class.

In the interviews, each teacher was encouraged to speak about their options when planning activities, and about their practices. Classroom observation focused on some specific features of classroom interaction and on students' attitudes during written tasks, such as the kind of questions asked (by students and teachers) and the time given to students to think about an answer. The interview transcripts and the observation reports were given to participants to confirm factual occurrences.

An inductive analysis of data (teachers' interviews, class reports and students' written tasks) was carried out during three phases to progressively refine data collection procedures and categorization. Although the essential methodology was qualitative, students' oral and written answers in class were analysed for frequency distribution. Data triangulation of interviews, class reports and written tasks provided a better understanding of possible relationships between the teaching practices and the way students learn and think in history. The categorization of the students' answers presupposed diverse levels of historical thinking (Ashby and Lee, 1987; Barca, 2000; Gago, 2005; Lee, 2001, 2005).

\section{Teaching and learning process: Profiles of teaching and learning moments}

Data analysis of teacher-student interaction during a whole lesson revealed different profile moments, rather than a single model per teacher, as shown in Figure 1.

Seven profiles of teaching and learning moments were found, from teachercentred moments to teacher-and-student-centred moments. The first profile focused on information delivery and questions addressed to students to produce simple information retrieval, assessed in a way that centred on feedback provided by content checklists similar to Bloom's taxonomy (1956). The last profile focused on students' activities at various levels of cognitive challenge, assessed through formative practices, based on constructivist approaches, and metacognition.

Data analysis of students' interventions revealed three levels of ideas (reproduction, interpretation and understanding). These formed the model of the development of competencies in history generated in this study. The first level means simple regurgitation. The second indicates autonomous answers, limited to fragmented inferences about sources and based mainly on previous common-sense ideas. The third level indicates answers revealing a reasoning that permits an understanding of change and/or continuity in a given past situation.

Although it was observed that a teacher usually developed diverse teaching moment profiles, thus fostering different types of learning moments, it was found that some teachers tended to vacillate between Profile 1 to Profile 4 (from mere transmission to some tasks developed through dialogue in class), while others tended to flow between Profiles 4 to 6 . The latter profile involved students in written tasks, in small groups, with time given to think, but with no discussion and synthesis of results. 
Only one teacher (out of six) produced moments of Profile 7. Profile 7 is discussed next, since it might be the most inspiring in the context of observed best practices.

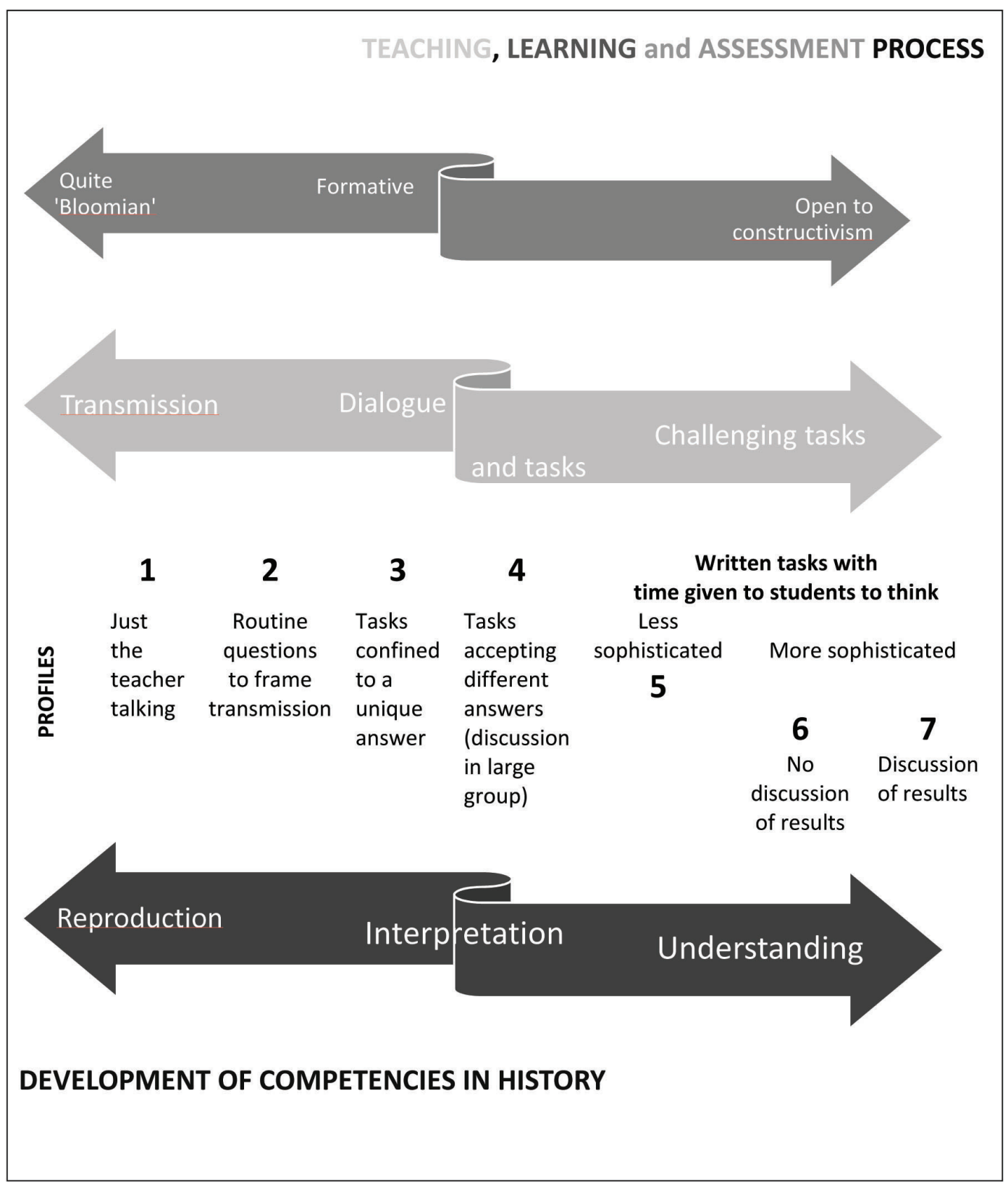

Figure 1: Different profile moments that may occur during a lesson

\section{Teaching and learning moments of Profile 7: Sophisticated written tasks - discussion of results}

The first data presented in this section describe some teaching and learning characteristics of the best practices considered as Profile 7. They provide some understanding of the context in which the researcher proposed an individual student task to teachers whose practices manifested moments of Profiles 6 and 7 (Profile 6 indicates sophisticated written tasks - no discussion of results). This proposal intended 
to achieve a more objective insight into students' learning in order to meet the aims of the research.

Several methodological characteristics stood out from the data analysis of classroom reports on the teaching and learning (and assessment) process:

(1) posing questions to be solved through interpreting historical sources

(2) formulating task objectives

(3) defining and negotiating work conditions (time, peer discussion, individual writing based on source interpretation)

(4) using formative assessment in a constructivist, metacognitive fashion

(5) scaffolding students' historical thinking

(6) creating relationships between students' commitment to learning and the way tasks were corrected in class.

During student task activities, the teacher provided feed forward to help students go further by building on a previous statement when interpreting evidence and change in history, rather than providing 'correct' answers. It was also observed that the students were always concerned about the need to argue in favour of what they were writing, because they were aware that their teacher would not simply accept copying from the textbook. Instead, she wanted them to express their own ideas, and would ask them to justify their answers. In fact, when a student said that he was going to copy from the textbook, another student warned him that, 'You're looking for trouble, the teacher doesn't like copies. The teacher wants us to think and justify, always justify, justify ...'

One example of scaffolding that was observed was the way in which the teacher dealt with students' doubts, giving back the questions to students, defying them to discuss and to produce deeper answers based on a closer examination of some elements of the sources available and on previous knowledge. In the interview (after class observation) the teacher recognized that it was the best way to help students to 'construct' historical thinking:

I prefer to scaffold their historical thinking in order to help them to reach the answer (if they have the conditions to do so). On the other hand, I think it is very important that they discuss their doubts with each other, to question historical sources themselves, to argue ... It seems to me that this is the way to empower students to construct their own thinking in history.

The relationship between the use of constructivist assessment and promotion of historical thinking practices was evidenced when the teacher gave feed forward on a complex historical issue, the Cold War. This promoted a peer discussion about the particular interests of the USA and the USSR in keeping specific areas of control. During this exercise of historical empathy, a student claimed: 'Oh! Now I understand what is going on in the world ...'

It was also observed that all students seemed committed to the task. They used teacher feed forward, asking them to think further about what they already knew, to improve their work. Most students engaged with this by presenting their task results either by reading their conclusions aloud or by asking if their ideas were acceptable. This reflected their experience of discussing ideas in class. In fact, students listened carefully when the teacher explained why some ideas were more valid than others in history. All of them wrote their own conclusions. These practices seemed to empower students in their historical thinking, social interaction and involvement. 


\section{Constructing students' ideas}

The students' answers discussed here resulted from the individual task proposed by the researcher about the changes that occurred in the world between the end of the Second World War and the Cold War (see Figure 2). It intended to explore how students developed their understanding of change and/or continuity in history in the light of available evidence. Only Questions 1 and 3 are displayed as they focus on change and continuity of relationships between the Allied countries. Other questions focused on evidence.

1. Why are the representatives of Britain, the USA and the USSR together in this photo (Source 1)? What did they intend to do?

$\cdots$

3. Knowing that the cartoon (Source 2) was made some years after the photo (source 1 ) was taken, what could have happened in the intervening years?

Source 1

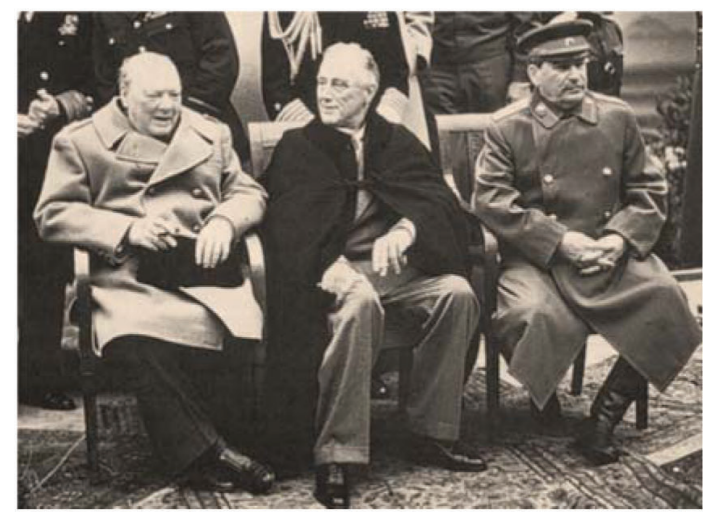

Churchill, Roosevelt and Stalin at the Yalta Conference in February 1945
Source 2

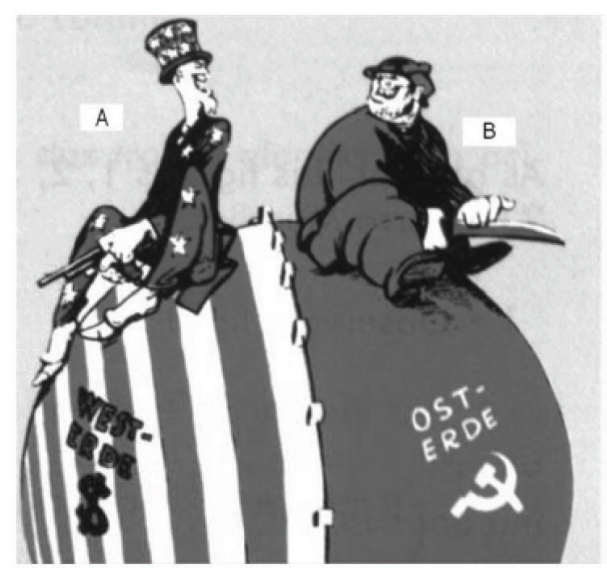

Cartoon about the Cold War (1950s)

Figure 2: The task posed by the researcher about changes in the world between the end of the Second World War and the Cold War

This task was previously discussed with both teachers (in the final study), and they agreed that it was better to use iconographic sources from the textbook that their students would recognize and that would help them to better grasp the idea of change between the historical moments. It was also decided with the teachers that the students could use the textbook (to contextualize), and that the task should be done in 15 minutes at the beginning of the second observed lesson, because by that time both classes would be studying the Cold War. 
During the task, most of the students revealed their interest in answering the questions, and both teachers gave them 15 minutes more so that they could complete the task. Most of the answers to Question 1 revealed that the students used their previous knowledge to interpret sources. The answers of the students that perceived the change in the Allies' relationship to achieve a common goal were categorized as 'Change perceived (based in general ideas)'. The following statement was selected as an example of this kind of answer: The USA, the USSR and the UK representatives are together in order to bring peace to the world' (Liliana, 14 years old). However, most of the answers were categorized as 'Change understood (and briefly explained)', as they revealed that the students understood that if the Allies were together, the world would change in some way. For example, Orlando (15 years old) stated, 'They were together because they intended to establish world peace and a new world order.' Just one student, Débora (14 years old), contextualized her answer, providing an intentional explanation: 'They understood that they should overcome their differences in order to correct the damage caused by Germany in the Second World War and they were at the conference to establish a new world order.' This answer was categorized as 'Change understood (and explained)'.

The best examples of understanding change and continuity were provided by some of the answers to Question 3: Knowing that the cartoon (Source 2) was made some years after the photograph (Source 1) was taken, what could have happened in the intervening years? For example, Marilia (15 years old), tried to give meaning to changes that occurred at the end of the Second World War, but she also recognized a subtle continuity when claiming that, 'at Yalta (Source 1), the enemies hated each other, but they signed a peace treaty; after that the Cold War happened and they made weapons, and although the cartoon shows them sitting next to each other, they are ready to attack.' The following example shows how Ivo (13 years old) mobilized substantive knowledge to 'construct' an explanation, by discussing causes and consequences:

The USA and the USSR were both part of the Allies at the end of the Second World War because they were against Germany and Japan and they intended to win the war. Nevertheless, when the war ended the USA and the USSR were no longer Allies because they had different social and economic models, so antagonism soon returned and this led to the Cold War.

These answers, in which the students distinguished and clarified aspects of change and continuity in the relationships between the Allies, were categorized as 'Change and continuity understood (and explained)'. In spite of these more elaborate ideas expressed by some students in answer to Question 3, most of the students only perceived change based on general ideas, as in the case of Cintia (14 years old): 'Between [what is portrayed in] the two sources, the world was split in two, many countries in the eastern world stood up for the USSR and the countries in the west stood up for the USA'.

In summary, we might conclude that the features of the task, and the way it was carried out, contributed to visible differences in results: students whose thinking reflected Profile 7 were more committed to the task than those whose thinking fitted Profile 6. In this profile, the answers were not discussed at the end, and many students did not bother to complete the task. Nevertheless, in Profile 6, a few answers to Question 3 revealed the understanding of change, such as that of Celina (14 years old): 'Because 
these nations became rival world superpowers and because they had weapons, each one intended to rule all over the world.'

Therefore, it was evident that students in Profile 7 produced more elaborate answers with more frequency than those in Profile 6. Indeed, the former were used to: (1) interpreting sources and justifying their ideas; (2) discussing different ideas, and reasoning about why some are more valid in history than others; and (3) producing 'historical' conclusions using evidence. Beyond that, students knew that their work would be assessed in a formative way at the end. Their teacher reiterated in the interview that 'the task was suitable for these students because they are used to interpreting historical sources and they like doing it.'

The results of these tasks on change and continuity in history, carried out by students in the context of their classroom activities, supported a proposal of levels of progression that might be useful to evaluate students' understanding concerning second-order historical notions (see Table 1).

Table 1: Categories of progression suggested by the research findings

\begin{tabular}{lll}
\hline Level & Category & Subcategory \\
\hline Incoherence & No reference to change or continuity & \\
1 & Change or continuity perceived & a) with inconsistencies \\
2 & Change and continuity perceived & b) general ideas \\
3 & a) with inconsistencies \\
4 & Change or continuity understood & b) general ideas \\
& Change and continuity understood & b) explained \\
& a) briefly explained
\end{tabular}

An initial level of incoherence relates to meaningless answers or tautological expression concerning change in history. Levels 1 and 2 relate to a sense of broad perception of change visible in descriptive (more or less consistent) accounts. Levels 3 and 4 give explanations in terms of (more or less relevant) causes and consequences. Another distinction across levels derives from the way in which change or continuity are presented. Answers only focusing on change or on continuity are considered as Level 1 or Level 3 according to perceptions or to explanations given. Likewise, answers considering simultaneous aspects of change and continuity are categorized as Level 2 or Level 4.

\section{Influences on teacher options}

The analysis of the interviews suggested three main influences on the teachers' options when planning their lessons: (1) planning conditions; (2) conceptions of teaching (and assessment); and (3) professional experiences. Among the several categories formed around these constructs, those related to the teacher who provided Profile 7 moments are described here.

Among 'planning conditions' in Profile 7, the categories that stood out were 'history as a challenge' and 'judicious curriculum management'. For the teacher interviewed below, challenging historical thinking is a way to engage students in reasoning and source analysis. As she said in the interview, 'Any challenge fosters their 
interest ... to construct evidence from sources.' This teacher also claimed that a teacher should master the history curriculum in order to create meaningful tasks as the best way of simultaneously developing historical thinking and dealing with the extensive syllabus: there is always, 'lack of time, but I always make students do activities because they must think'.

This attitude was linked to a concern for 'task-centred practices' and 'the use of formative assessment' relating to 'conceptions of teaching (and assessment)'. This teacher was aware of the importance of written tasks - whether carried out individually or in groups - to develop students' competencies, because some other pedagogical practices tend to exclude those students who do not feel at ease with participating in oral activities in class. She also underlined the fact that Portuguese classroom practices are mostly based on oral teaching and, in contradiction with that, they rely almost entirely on summative assessment from written tests, which are the only opportunity given to students to write in class:

Written tasks are thought to help students to focus on source analysis and to outline the main ideas. That is considered a mental operation equal to problem solving. It is considered better than dialogue because there is, allegedly, always someone who does not participate. Sadly, most of our teaching is based on the oral skills of the teacher, while students only write in tests.

The interview continued with this teacher contrasting this approach with her belief that history lessons should be supported by using formative assessment in a constructivist approach. A teacher should take students' thinking forward, extending what they know and can do, including individual reflection and open discussion of results at the end of the lesson:

It is important to listen to students and to discuss with them what is more valid in history and what is not - and why. This practice feeds their interest in thinking about the 'whys' of history. And in the search for evidence they can ask their peers - or the teacher - for help.

Among 'professional influences', this teacher highlighted the importance of continuous teacher education, specifically in history education, based on projects such as the Historical Consciousness project fostering significant changes in teaching and learning practices:

I had the privilege of attending some workshops ... on history education. They made me wonder about what I was doing in my lessons and helped me to improve my practices in order to make my students think about history ... And now most of them consider history to be an interesting subject.

It is important to say that several participant teachers also knew of the existence of history education, but they did not attend any teacher education in this area. The need for continuous education was evoked from the reflective habit of this teacher, who sometimes found herself questioning how to teach a class in order to promote learning: 'What am I going to do in order to make them learn?'

\section{Students' metacognition}

The analysis of the answers to the metacognitive task proposed by the researcher revealed that most of the students recognized that they learnt better (more significantly) 
when they had to search for evidence in the context of the sources from the past, in order to provide meaning to the historical challenges posed in the classroom. They also highlighted the importance of reasoning about history and the expression of ideas by writing; as Alexandra ( 15 years old) said, 'by answering questions (by writing them) we learn a lot'. Elisa (14 years old) claimed, 'as we argue about "historical things", they became more interesting'.

The influence of teacher feedback on the way they were learning, and the importance of interaction with peers, was also pointed out by several students, such as Adalgisa (14 years old): 'I learnt with the help of the teacher and my colleagues.' The importance of knowing what they were expected to do in class was also acknowledged by some students, who said that it helped them to learn and to accomplish the tasks proposed. 'This way of learning is very good. Our teacher explains what we have to do very well' (Veronica, 14 years old).

\section{An outline of some final considerations}

The teaching practices observed in a class mainly based on Profile 7, 'sophisticated written tasks - discussion of results', appeared to have a positive influence on the development of the students' historical competencies, as well as on a learning process within an organized, friendly and fruitful classroom interaction. When preparing the teaching and learning process, three teaching influences stood out:

(1) knowledge and understanding of the main principles proposed by history education research assisted in choosing the most suitable practices to foster students' historical thinking (which tentatively includes a disciplinary approach, namely developing competencies in source interpretation and understanding)

(2) the knowledge of the curriculum and its syllabus allowed the teacher to construct 'criterion management' of student tasks around substantive and secondorder concepts

(3) the use of a pro-constructivist assessment was considered as important to promote understanding.

This kind of professional development revealed a personal commitment to searching for innovative and effective ideas in order to gain teaching competencies to enable better learning in today's complex society. The fact that the teacher who exhibited Profile 7 moments had systematically attended history education workshops (promoted in Lisbon), showed that a sound knowledge in this area can foster better practices towards the development of temporal orientation. It suggests that teachers should invest in their own professional development by attending continuous education courses and by maintaining a reflective attitude towards their own performance in class, in light of updated, sound proposals.

Continuous education courses can also suggest some ideas in terms of 'rules of thumb' in class management, as one teacher revealed:

(1) ability to set task conditions and objectives, as it allows students to organize themselves and to know what to do and how

(2) incidence of promoting peer discussion to foster student involvement in arguing and thinking in history

(3) assign relevance to the need to give written tasks to increase reflection and communication skills

(4) preference for providing feed forward and scaffolding students' thinking to help students' conceptual progression. 
The results of this study provided a more objective picture of students' learning, and in some ways highlighted how teaching and learning (and assessment) practices might influence students' thinking in history. In a lesson centred on transmission and regurgitation of given historical content, students tend to reproduce information, and rarely show signs of their own ideas (such as was observed in classes with Profiles 1 to 3 ). In those contexts, perhaps a few students would wish to manifest their historical ideas, but there are few opportunities for that and, when it happened, they were scarcely valued. In Profiles 4 and 5, students tend to manifest simple ideas and, again, when more sophisticated ideas appear, they are barely valued in class dialogue. Profile 6 might instil more elaborate thinking, but the progression is not monitored sufficiently. The best practices moments observed (Profile 7) presented some clues as to how some teachers in Portugal are trying to foster students' historical thinking in a more grounded way.

It must be said that these findings derive from an essentially qualitative analysis of data with a restricted set of participant teachers. Therefore, the results cannot be generalized, although they can provide a useful insight into what is occurring in some Portuguese history classrooms.

\section{Notes on the contributor}

Mariana Lagarto is Investigator in History Education at CITCEM, University of Porto, with a PhD in history education and social sciences, and a master's degree in assessment in education. Mariana has been a secondary school history teacher, a member of the History Teachers Association Board and a teacher trainer. Mariana is the author and co-author of articles on assessement for learning and history education, and co-author of teaching handbooks of history in Portugal, and of history of culture and arts in East Timor.

\section{References}

Alves, M.P. and Machado, E.A. (2011) 'O sentido do currículo e os sentidos da avaliação'. In Alves, M.P. and De Ketele, J.-M. (eds) Do Currículo à Avaliação, da Avaliação ao Currículo. Porto: Porto Editora, 59-70.

Ashby, R. (2003) 'O conceito de evidência histórica: exigências curriculares e concepções de alunos'. In Barca, I. (ed.) Educação Histórica e Museus: Actas das segundas jornadas internacionais de educação histórica. Braga: CIED, Universidade do Minho, 37-57.

Ashby, R. and Lee, P. (1987) 'Children's concepts of empathy and understanding in history'. In Portal, C. (ed.) The History Curriculum for Teachers. London: Falmer Press, 62-88.

Ashby, R., Lee, P.J. and Shemilt, D. (2005) 'Putting principles into practice: Teaching and planning'. In Donovan, M.S. and Bransford, J.D. (eds) How Students Learn: History, mathematics, and science in the classroom. Washington, DC: National Academies Press, 79-178.

Barca, I. (2000) O Pensamento Histórico dos Jovens: Idéias dos adolescentes acerca da provisoriedade da explicação histórica. Braga: Universidade do Minho.

Barca, I. (2004) 'Aula Oficina: Do Projecto à Avaliação'. In Barca, I. (ed.) Para uma Educação Histórica de Qualidade: Actas das Quartas Jornadas Internacionais de Educação Histórica. Braga: Universidade do Minho, 131-44.

Barca, I. (2011) 'Narrativas Históricas de Alunos em Espaços Lusófonos'. In Barca, I. (ed.) Educação e Consciência Histórica na Era da Globalização. Braga: CIED, Universidade do Minho, 7-27.

Bloom, B.S. (ed.) (1956) Taxonomy of Educational Objectives: The classification of educational goals: Handbook l: Cognitive domain. New York: David McKay Company.

Cooper, H. and Chapman, A. (eds) (2009) Constructing History 11-19. London: SAGE Publications.

Corbin, J. and Strauss, A. (2008) Basics of Qualitative Research: Techniques and procedures for developing grounded theory. 3rd ed. Thousand Oaks, CA: SAGE Publications.

Erickson, F. (1985) Qualitative Methods in Research on Teaching (Occasional Paper 81). East Lansing, MI: Institute for Research on Teaching. 
Fernandes, D. (2011) 'Articulação da aprendizagem, da avaliação e do ensino: Questões teóricas, práticas e metodológicas'. In Alves, M.P. and De Ketele, J.-M. (eds) Do Currículo à Avaliação, da Avaliação ao Currículo. Porto: Porto Editora, 131-42.

Gago, M. (2005) 'Children's understanding of historical narrative in Portugal'. In Ashby, R., Gordon P. and Lee P. (eds) Understanding History: Recent research in history education (International Review of History Education 4). London: RoutledgeFalmer, 77-90.

Lee, P. (2001) 'Walking backwards into tomorrow: Historical consciousness and understanding history'. International Journal of Historical Learning, Teaching and Research, 4 (1), 1-45.

Lee, P.J. (2005) 'Putting principles into practice: Understanding history'. In Donovan, M.S. and Bransford, J.D. (eds) How Students Learn: History, mathematics, and science in the classroom. Washington, DC: National Academies Press, 31-77.

Patton, M.Q. (1990) Qualitative Evaluation and Research Methods. 2nd ed. Newbury Park, CA: SAGE Publications.

Roldão, M.C. (2003) Gestão do Currículo e avaliação de competências - as questões dos professores. Lisboa: Editorial Presença.

Rüsen, J. (2004) 'Historical consciousness: Narrative structure, moral function, and ontogenetic development'. In Seixas, P. (ed.) Theorizing Historical Consciousness. Toronto: University of Toronto Press, 63-85. 